\title{
The Oral Historian as Memorist
}

\author{
by Paula Hamilton
}

\begin{abstract}
This paper explores some issues in relation 10 oral history and memory that emerge in Alessindro Portelli's The Order Has Been Carred Out. I examine the contemporary role of the oral historian. the relationship between the present and the past in memory work. and make some comments about how we might articulate the field of oral history with memory studies more closely for the enrichment of both.
\end{abstract}

I am from Australia and someone who brings another perspective to this Euro-American exchange since Portelli's work is known widely throughout the world: his work speaks to many people. his books are on all the reference lists for students. his examples bring fragments of the Italian past into our (in my case, postcolonial) lives.

I have three issues that I will address today-so I will outline them briefly and then comment on the hook and elaborate my points:

1. The first point broadly relates to the contemporary role of the oral historian.

2. The second concerns the scholarly context. I want to make some remarks about present/past relationships in history

Associate Professor Paula llamilton bas taught history at the University of Technology Sydney for several vears and worked in a range of oral history profects with communit! groups musetums. heritage agencies and local councils. She is the co-author (with Katc DarianSmith) of Memory and History in Twenterh Cennmy Australiu (Oxford Lnisersits Press 1994 ) and has published widely un pullic numory and historical consciousness in Australia. She is cumenty completing a book (with Paul Ashlon) for Halstead Press and tho National Museum of Australia titled What is Histom in

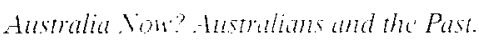

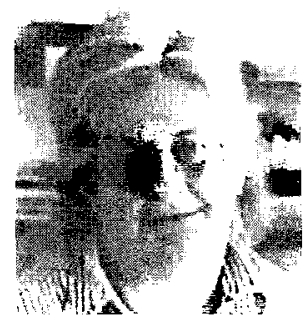

The Oral History Revien. Vol. 32, Issue 1, pp. 11-18. ISS. 0094-1223, clectronic ISSN I533-8592. (c) 2005 by the Oral History Association. All rights reserved. Please direct all requests for permission to photocops or reproduce article content through the Lniversity of California Press Rights and Perminvions website, at http:/www.ucpress,edu/journals/rights.htm. 
writing and factors that shape how we view the past and remember it.

3. Finally, I want to ask about the impact of memory studies scholarship and how we articulate oral history with memory as fields of study. I will make some comments here more by way of suggestion since there is no time or space to elaborate.

\section{The Role of the Oral Historian}

Let's begin by historicizing Alessandro Portelli himself. Born in 1942 he is one of a generation of European historians whose lives have been shaped not by living consciously through the war, but by growing up with the close memory of the war as experienced by others and passed down to them, with the material legacies of death and destruction all around. He follows this event's history through to his children and in this sense the book is very much an inter-generational story.

The adult generation who lived through the war are dying. This is one of the reasons given as the driving force behind the boom in memory studies, but I think of this phenomenon more broadly: a single factor does not explain or link sufficiently with what is happening in various societies and we have yet to seek comparisons on the ground, so to speak, between countries.

Throughout the book Portelli positions himself not so much directly against historians, but not of them. He marks himself out by referring to a comment that Fosse Ardeatine had been widely written about but was an "event made unknowable by a surfeit of historians." I think this allows him a certain kind of scholarly freedom, freedom to play on the interdisciplinary margins; Portelli positions himself against historians on the one hand, yet utilizes history throughout-and thus subtly shows how close but how far apart History as a formal discipline and histories as vernacular storytelling are (this may also have to do with the unease about the place of oral history within the history discipline itself and his position as a literary scholar and activist). So while History is the referent point, Portelli questions conventional notions of historical significance and periodization by arguing that Fosse Ardeatine is not a single self-enclosed event. 
His investigation ranges across sixty years back and forth from the reporting and remembering of the event to its commemoration.

How does Portelli himself see his role? Early in this book Portelli says he wants to make an "intervention" but the nature of it remains elusive. This book surely does more than "amplify the voice," a famous Portelli phrase, or place other accounts in the public domain. On the one hand we might speculate that usually the function of a book made of stories is to generate other stories, to feed the cycle of remembering. But with disarming honesty Portelli explains that it is "not only for reasons of civil morality but because it was a unique intellectual and methodological challenge" (p. 15). Here is both the scholar and the activist working together to extend the boundaries of what is possible in oral history.

But the obligation to speak is insistent: In this book, Portelli speaks "for the sake of the story that needed to be told": "So many times," he says, "in allusions, suggestions and fragments, the members of the generation of the resistance and the relatives of the killed at the Fosse Ardeatine have asked me: who will tell this story after we are gone?" (p. 19). The answer is of course Alessandro Portelli himself. He is the mediator between generations.

We are then confronted with responsibility for remembering. I don't think Portelli is arguing (as many others do) that the act of remembering itself is potentially transformative or that the divided memory becomes less divisive in the present. Nor is he making a claim for the therapeutic model of memory-the idea that the truth itself will bring reconciliation is a doubtful assumption, as the many Truth and Reconciliation Commissions have taught us. As Avishai Margalit argues "memory breathes revenge as often as it breathes reconciliation."

It seems to me that the power of an imagination such as Portelli's can activate different pasts to become meaningful in the present. To struggle with the past is also to pose questions of the present-what the past means in the present. This is exactly what Portelli does. He explores ways of taking the past forward which emerge from the idea that the present is obliged to accom-

${ }^{1}$ Avishai Margalit. The Ethics of Memory (Cambridge. MA: Harvard University Press, 2002), 5. 
modate the past in order to move on from itself. (It is also of course a historically specific way of thinking about history in the twenty-first century.)

\section{The Scholarly Context}

Portelli's is one of a growing number of books that have overcome the breach between the historical reconstruction of an event and how it is remembered. The work of my fellow panelists are two wonderful examples of this and collectively we begin to see the impact of the turn to memory in historical work. This book and its beautifully elegiac tone, operates within that turn to memory in our societies, or what I understand as a growing culture of commemoration through which we interpret the meaning of the past. In this process memory and history have become closely entangled as I said earlier. Dipesh Chakrabarty offers an interesting explanation: "democratic historywriting still calls on us to listen to the voice of experience, but experience as a category speaks more to memory than the discipline of history - the more we attend to experience the more memory and history get entangled." In the turn to memory in our societies, we find that there is not only interest in making sense of history but its sensibility (what was it like, how do we live in history, how are we aware of ourselves as historical beings). These sensibilities are central to Portelli's engagement with his narrators. It is in oral histories where the collapse of the past/ present relationship is most marked because some degree of distance is always present in memory writing. Being confronted with the embodied memory and its individual particularity in relation to this event has profound consequences

Thus we can see that Portelli's work while having remarkable continuity with his previous books, also reveals a more recent concern with broader shifts in historical consciousness, historicity, and new self-consciousness about the past.

Evidence of this can be seen for instance in Portelli's changed attitude to place, to his place. He says, "In Rome history wears

\footnotetext{
${ }^{2}$ Dipesh Chakrabarty, "Museums in Late Democracies," Humanities Research, "The Future of Museums/Museums of the Future," part 2 (Canberra: Australian National University Humanities Research Centre, 2002), 8-9.
} 
a capital $\mathrm{H}$, and its burden seems to frustrate, and annihilate the work of memory or to make it seem irrelevant. Too often history is a far away sphere, distant from the daily lives of its people or a crushing annihilating weight upon them" (p. 9). He is arguing here that through this project he learns to know his city differently; and as a result a different kind of historical consciousness has emerged-a lived sense of history, not an exotic different estranged past but one where there is continuity with his own life. In doing this he questions the distancing effect of a traditional history cut off from the present.

Throughout this book, Portelli interweaves the writer's narrative with that of his oral history narrators. He recognized what many others have ignored: that once we take into account the eyewitness's voices, their apprehension or misapprehension of events, their reflexive interpretation of experience, we understand more deeply how people responded to unfolding events as they did. Moreover, that continuing narrative grasp of events by participants was very much a part of the historical reality itself. One cannot separate the experience from the telling of it.

This process restores a measure of contingency to historyopening up possibilities of different knowledges, not only those possible with hindsight. The narrators' memory includes experiences of both history and memory: the ways memory has already become part of personal history, the ways misunderstandings, rumors, and silences were part of what happened then and part of the memory as it is told now.

Truly here a cultural history of remembering-he shows the importance of symbols, rituals, and language and use of public spaces in coming to terms with episodes of collective violence. Through the memory of the event, we see the systematic way in which emotions are tied to the Fosse Ardeatine. He shows generational shifts in the process of remembering and forgetting but refuses the binary categories of "victim" and "perpetrator." Portelli describes how during the war it was possible both to suffer and to cause suffering in others. Nonetheless a broad array of groups is attempting to shape the historical consciousness of societies in the aftermath of collective violence where wounds remain open across generations; so the memory is always left unresolved, unfinished.

Another principal concern in recent scholarship is related 
to the cultural forms that are utilized to shape memories of the past. Portelli has mentioned the production of histories, of written accounts in the public arenas, but not especially of the visual forms such as photographs and films. (He has referred to Schindler's List and Rome: Open City only in relation to the generalized memory of World War II.) Later generations arguably will gain a much greater part of their historical understanding from the media-film, television, and so on-have television documentaries and film clips also shaped the generational remembering here?

We know that for younger generations, access to the mnemonic communities or "communities of memory" which are generally available about the past (families, for example) can falter if there is no publicly consensual account of events as in this case. However, Alessio Salvatori, one of the book's narrators, says it is not possible to forget-the memory of Fosse Ardeatine is everywhere (he seems weary of remembering in some ways): "One may not have specific knowledge of what happened, but one knows anyway because living in Rome, living in that neighbourhood, every year there are ceremonies or something, it is always commemorated, it is not a thing which sinks into oblivion" (p. 7).

Thus the anniversaries, the commemorations, the street names, the ceremonies, the plaques, all contribute to remembering for those directly affected - but what of the wider Roman society for whom the memory has lost its specificity as it is passed down? I know that as a result of Portelli's work, this book has been made into a theatre performance that will surely reach a different audience; and this form will encourage a more diverse remembering. Maybe Portelli's intervention in the process by which memories are circulated and made public will ensure a more enduring heritage.

\section{Oral History and Memory Studies}

A decade ago, by then a well-established oral historian, I began to explore and write about the emergence of memory studies by historians as a way forward in my hunger to contextualize the stories I was working with beyond the "murmuring of innumerable lives." Was history after all a form of collective 
biography? I was exploring possibilities not just in relation to the content of my historical work but in relation to historiography and methodology as well. For a variety of reasons it seemed to me that my research could no longer be an exercise in which I had a topic to explore and wanted to illuminate it through oral histories (though of course this remains the most prominent and valuable way to proceed). I was already doing what Mike Frisch had so presciently called "exploring what it meant to remember" (forgetting, misremembering, silences, and so forth) and I began to see that the single act of memory work which was the oral history interview was just the tip of the icebergthat I was an active agent in the process of creating memoriesmaking memory social; and that rather than fetishize the interview and what went on there, I needed to think more broadly about what oral history does in relation to other areas of my work in museums, historic sites, and so forth. At the same time I felt that sometimes during the interviewing process one came up against the limits of oral histories. It was such an intimate relationship and the boundaries between history, psychologizing, and therapy were very quickly erased. In addition, how people related the past in the present seemed always to be so arbitrary, fashioned by a complex range of factors operating as much in the past as the present. What people remembered depended on who they had talked with, what television or film they'd seen of the event, and I began to understand better how remembering was a constant ongoing revision, a dynamic process, and to see that there was no organic memory of an event.

A decade later some of the trends I explored then have accentuated considerably, so that not only is there an explosion of memory scholarship much of which has now little to do with oral history, but there is also an increased democratization of remembering and commemoration: people are doing it for themselves; and a new self-consciousness about history and memory and its cultural role in our societies. The democratic and very diverse practice that is oral history is now only one form of remembering/mourning/expressing loss. (Much oral history is about loss, or preventing loss.)

But what can I say ten years later that I have learned from this explosion of scholarship, from the non-oral work in memory? 
Just briefly, there is hardly now any distance between history and memory, they have become so entangled. We seem to have become much more aware of the role of time, of shifting temporal sensibilities, and of the politics of time and memory. In relation to scholarship, we often expect memory studies to explain too much, and there are many unresolved methodological issues in the field.

Some people are suspicious that the conscious lived sense of the past, the recouping of the past through oral history projects with groups and individuals, has been overshadowed by the ever encroaching analysis of memory, with a focus on the unconscious - they are worried about the absence of agency in studies of collective memory. Conversely, others in oral history are beginning to feel that there is far too much focus on agency in the oral history exchange and practice.

Why is there not greater dialogue between scholars of memory and oral historians? I think it is partly a problem of the histories of different areas of study and the accident of interdisciplinary trajectories. But one of the major reasons is what I will call "one way traffic," that is, the assumption that oral history is a "method" that needs to be broadened by a wider theoretical context; the fetishization of practice has not helped this. However, I believe that we have only just begun to explore the possibilities of remembering and the voice-the innovative research in aurality and orality (listening and voice histories) is a way forward providing new directions for oral historians and so is its role in exploring the history of the emotions and the senses (smell, touch, and hearing). But we have to work harder. Oral history never was just a form of evidence as Portelli's work so eloquently shows. 


\section{The Oral History Review \\ Published by the \\ University of Calitomio Press \\ for the Orol History Associotion}

